\title{
Pre-Hematopoietic Stem Cell Transplant Lung Function and Pulmonary Complications in Children
}

\author{
Ashok Srinivasan ${ }^{1,2 \star}$, Saumini Srinivasan ${ }^{2 \star}$, Sudeep Sunthankar ${ }^{3}$, Anusha Sunkara ${ }^{4}$, Guolian Kang ${ }^{4}$, Dennis C. Stokes ${ }^{2}$, \\ and Wing Leung ${ }^{1,2}$ \\ ${ }^{1}$ Department of Bone Marrow Transplantation and Cellular Therapy, St. Jude Children's Research Hospital, Memphis, \\ Tennessee; ${ }^{2}$ Division of Pulmonology, Department of Pediatrics, University of Tennessee Health Science Center, Memphis, \\ Tennessee; '3 Medical University of South Carolina, Charleston, South Carolina; and ${ }^{4}$ Department of Biostatistics, St. Jude Children's \\ Research Hospital, Memphis, Tennessee
}

\begin{abstract}
Rationale: Pulmonary complications are a significant cause of morbidity and mortality after allogeneic hematopoietic stem cell transplantation.
\end{abstract}

Objectives: The relationship between pretransplant pulmonary function tests (PFTs) and development of post-transplant pulmonary complications in children was studied.

Methods: This is a retrospective single institution cohort study of 410 patients who underwent pretransplant PFT and were monitored to 10 years posttransplant.

Measurements and Main Results: Pulmonary complications were observed in 174 (42\%) patients. Children with pulmonary complications had significantly lower forced expiratory flow at $25-75 \%$ of vital capacity $(P=0.02)$ derived using conventional predicted equations for age, and the Global Lung Initiative-2012 predicted equations $(P=0.01)$. T-cell depletion $(P=0.001)$, acute grade $3-4$ graft-versus-host disease $(P=0.008)$, and chronic graft-versus-host disease $(P=0.01)$ increased risk for pulmonary complications. Patients who had pulmonary complications had a 2.8 -fold increased risk of mortality $(P<0.0001)$. The cumulative incidence of death due to pulmonary complications was significantly higher in children who had low lung volumes, FRC less than $50 \%(P=0.005)$, TLC less than $50 \%$ $(P=0.0002)$, residual volume less than $50 \%(P=0.007)$, and $\mathrm{T}$-cell depletion $(P=0.01)$. Lower $\mathrm{FEV}_{1}(P=0.0005)$, FVC $(P=0.0005)$, TLC $(P<0.0001)$, residual volume less than $50 \%(P=0.01)$, and restrictive lung disease $(P=0.01)$ predicted worse overall survival.

Conclusions: Abnormal pretransplant PFT significantly increased risk after transplant. These patients may benefit from modified transplant strategies to reduce morbidity and mortality.

Keywords: pulmonary function; pediatric; post-transplant complications

(Received in original form July 10, 2014; accepted in final form October 7, 2014)

*These authors contributed equally to this work and should be considered as co-first authors.

Supported by 5R25CA02394 from the National Cancer Institute (NCI), NCl Cancer Center CORE Support Grant P30 CA 21765, and the American Lebanese Syrian Associated Charities.

Author Contributions: All authors contributed to and approved the final draft of the manuscript. Conception and design, As.S., Sa.S., D.C.S., and W.L. Analysis and interpretation, As.S., Sa.S., Su.S., D.C.S., W.L., An.S., and G.K. Data collection and analysis, As.S., Su.S., An.S., and G.K. Manuscript preparation, As.S., Sa.S., D.C.S., An.S., G.K., and W.L.

Correspondence and requests for reprints should be addressed to Ashok Srinivasan, M.D., Department of Bone Marrow Transplantation and Cellular Therapy, St. Jude Children's Research Hospital, 262 Danny Thomas Place, MS 1180, Memphis, TN 38105-2794. E-mail: ashok.srinivasan@stjude.org

Ann Am Thorac Soc Vol 11, No 10, pp 1576-1585, Dec 2014

Copyright (C) 2014 by the American Thoracic Society

DOI: 10.1513 /AnnalsATS.201407-3080C

Internet address: www.atsjournals.org

Allogeneic hematopoietic stem cell transplantation (HSCT) is a curative modality for children with certain hematologic malignancies and nonmalignant disorders. Posttransplant pulmonary complications contribute significantly to the morbidity and mortality from this procedure (1).
In a retrospective series of 90 children with malignant and hematological diseases, a subgroup of 7 (8\%) children developed bronchiolitis obliterans after HSCT. These children had significantly lower forced expiratory flow during the midportion of vital capacity $\left(\mathrm{FEF}_{25-75 \%}\right)$ at diagnosis (2).
Reduced pretransplant $\mathrm{FEV}_{1}$ and $\mathrm{FVC}$ in children were associated with higher risk of early respiratory failure, but did not affect overall survival (OS [3]). A worse pretransplant Lung Function Score (LFS), a combined measurement of $\mathrm{FEV}_{1}$ and single-breath diffusing capacity for carbon 
monoxide $\left(\mathrm{DL}_{\mathrm{CO}}\right)$ in children, was associated with poor survival (4). However, OS is confounded by mortality due to relapse, which is the predominant cause of death post-transplant. The relationship between pretransplant pulmonary function tests (PFTs) and post-transplant pulmonary complications, either infectious or noninfectious, has not been well studied.

We hypothesized that pretransplant PFTs may predict the risk of developing pulmonary complications, and the cumulative incidence of death from this entity. Our population includes the largest retrospective cohort of children studied to date with a follow-up extending up to 10 years posttransplant. Spirometry results were analyzed on the basis of the commonly used prediction equations $(5,6)$ as well as the more recent Global Lung Initiative (GLI)-2012 predicted values (7).

\section{Methods}

The retrospective cohort consisted of 786 patients less than 21 years of age who underwent a first allogeneic HSCT during a 20-year period (January 1990 through December 2009) at St. Jude Children's Research Hospital (SJCRH, Memphis, TN). Patients younger than 6 years of age (273 patients) were excluded as they were unable to perform PFT. Patients who either did not undergo pretransplant PFT, or had a noninterpretable result (103 patients), were also excluded. The final cohort consisted of 410 patients. The study was approved by the SJCRH Institutional Review Board. Patients were monitored for 10 years after transplantation. Follow-up was frequent in the first 2 years after transplantation, and yearly thereafter. The mean duration of follow-up for surviving patients who underwent pretransplant PFT was 6.7 years (range, $8 \mathrm{mo}-10 \mathrm{yr}$ ).

Patient-related variables were abstracted from a prospectively collected database that included patient demographics, underlying diagnosis, donor and product type, cytomegalovirus donor/recipient (CMV D/R) status, conditioning regimen, and graft-versus-host disease (GVHD) grading if present. The conditioning and GVHD prophylaxis have previously been described $(8,9)$. Conditioning regimens were classified as reduced intensity (RIC) and myeloablative (MAC). Patients in the MAC group included those who received either total body irradiation (TBI) equal to or exceeding $5 \mathrm{~Gy}$ in a single dose or at least 8 Gy fractionated; busulfan at more than $9 \mathrm{mg} / \mathrm{kg}$; or melphalan at more than $150 \mathrm{mg} / \mathrm{m}^{2}$. Patients in the RIC group received a fludarabine-based regimen. Ex vivo T-cell depletion of the graft was performed with anti-T-cell antibodies and complement in 53 patients $(29 \%)$ or by immune-magnetic selection, using the CliniMACS system (Miltenyi Biotec $\mathrm{GmbH}$, Teterow, Germany) in 129 patients (71\%). All patients who received haploidentical transplants received T-celldepleted grafts. Assessment of acute GVHD was based on consensus criteria (10).

\section{Infectious Pulmonary Complications}

Microbiology records were reviewed to identify patients with documented bacterial, fungal, and viral pulmonary infections as diagnosed by respiratory culture (bacteria, fungi, viruses), direct fluorescent antibody testing, and PCR (viruses). Pulmonary infection was defined as isolation or detection of an organism that was associated with symptoms, signs suggestive of lower respiratory tract involvement, or a new lung infiltrate on radiography. This included fungal and viral pathogens detected on preemptive screening. Specimens included nasopharyngeal wash, tracheal aspirate, bronchoalveolar lavage, blood cultures, and lung autopsy. The date of infection was recorded as the day the organism was detected.

\section{Noninfectious Pulmonary Complications}

Noninfectious pulmonary complications included idiopathic pneumonia syndrome, diffuse alveolar hemorrhage, bronchiolitis obliterans syndrome (BOS), cryptogenic organizing pneumonia (COP), and interstitial lung disease as described previously $(11,12)$.

\section{Pulmonary Function Testing}

Spirometry, body plethysmography, and diffusing capacity were performed in the pulmonary function laboratory at SJCRH by a certified technician in accordance with the American Thoracic Society/European Respiratory Society guidelines (13), using a Platinum Elite DX series body plethysmograph (Medgraphics, St. Paul, $\mathrm{MN})$. All tests were performed as part of routine clinical care in the 2 months before transplant. Pulmonary function testing consisted of spirometry including FVC, $\mathrm{FEV}_{1}, \mathrm{FEV}_{1} / \mathrm{FVC}$, and $\mathrm{FEF}_{25-75 \%}$. Lung volume measurements included TLC, FRC, and residual volume $(\mathrm{RV})$. $\mathrm{DL}_{\mathrm{CO}}$ was corrected for hemoglobin content. All pulmonary function values, except for $\mathrm{FEV}_{1} / \mathrm{FVC}$ ratio, were expressed as a percentage of the predicted values.

Spirometry values were normalized for sex, height, and age according to reference equations by Wang and colleagues (6-18 yr [5]) and Hankinson and colleagues (more than 18 yr [6]). Lung volumes were normalized according to reference equations by Stocks and Quanjer (14). Lung volumes in African Americans were adjusted with a fixed (0.88) correction (13). Diffusing capacity was normalized $(15,16)$. GLI-2012 predicted values and their lower limits of normal (LLN) for FVC, $\mathrm{FEV}_{1}, \mathrm{FEV}_{1} / \mathrm{FVC}$, $\mathrm{FEF}_{25-75 \%}$, and $\mathrm{z}$-scores were obtained with software made available by the GLI group (7). Obstructive lung disease (OLD) was defined on the basis of these equations as $\mathrm{FEV}_{1} / \mathrm{FVC}$ less than LLN. Restrictive lung disease (RLD) was defined as TLC less than $80 \%$ predicted. Grading of the severity of obstruction was performed according to Quanjer and colleagues (17). Calculation of LFS was as previously reported (18).

\section{Statistical Analysis}

The descriptive statistics for patients with and without pulmonary complications including infectious and noninfectious complications were reported, and compared either by Pearson chi-square test or Fisher exact test for categorical variables, and by two-sample $t$ test or Wilcoxon rank-sum test for quantitative variables based on normality assumption criteria. PFT outcome variables were compared for patients with or without pulmonary complications. Logistic regression analyses were performed to evaluate the associations between pulmonary complications, PFT variables, and covariates outlined below.

Overall survival probabilities were estimated by the Kaplan-Meier method and compared by log-rank test. Overall survival was defined as the time from pretransplantation PFT until death from any cause, censoring those alive at last follow-up. The Cox proportional hazard regression model was used to evaluate the associations between survival function, PFT variables, and covariates outlined below. The assumption of proportional hazard 
Table 1. Demographics and characteristics of patients who underwent pre-hematopoietic stem cell transplantation pulmonary function testing at St. Jude Children's Research Hospital between 1990 and 2009

\begin{tabular}{|c|c|c|c|c|}
\hline Characteristic & $\begin{array}{l}\text { All Patients } \\
(n=410)\end{array}$ & $\begin{array}{l}\text { Patients with Pulmonary } \\
\text { Complications } \\
(n=174)\end{array}$ & $\begin{array}{l}\text { Patients without Pulmonary } \\
\text { Complications } \\
\text { (n=236) }\end{array}$ & $P$ Value \\
\hline \multicolumn{4}{|l|}{ Age at transplant, yr } & 0.12 \\
\hline Mean (SD) & $13.5(3.81)$ & $13.8(3.9)$ & $13.2(3.72)$ & \\
\hline Median (range) & $13.6(6.2-20.9)$ & $14.0(6.2-20.9)$ & $13.4(6.2-20.7)$ & \\
\hline $6-10$ & $92(22)$ & $34(20)$ & $58(25)$ & 0.09 \\
\hline $11-18$ & $266(65)$ & $111(64)$ & $155(65)$ & \\
\hline 18 to $\leqslant 21$ & 52 (13) & 29 (16) & $23(10)$ & \\
\hline Males & $242(59)$ & $100(58)$ & $142(60)$ & 0.61 \\
\hline \multicolumn{4}{|l|}{ Race } & 0.20 \\
\hline White & 302 (74) & $123(71)$ & $179(76)$ & \\
\hline African American & 66 (16) & 32 (18) & $34(14)$ & \\
\hline Hispanic & $33(8)$ & $18(10)$ & $15(6)$ & \\
\hline Other & $9(2)$ & $1(1)$ & $8(4)$ & \\
\hline \multicolumn{4}{|l|}{ Diagnosis } & 0.77 \\
\hline ALL & $117(29)$ & $50(29)$ & $67(29)$ & \\
\hline AML & $115(28)$ & $53(30)$ & $62(27)$ & \\
\hline CML & $42(10)$ & $20(11)$ & $22(9)$ & \\
\hline Lymphoma & $22(5)$ & 7 (4) & $15(6)$ & \\
\hline MDS & $35(9)$ & $13(7)$ & $22(9)$ & \\
\hline Solid tumors & $21(5)$ & $6(3)$ & $15(6)$ & \\
\hline Hematologic disorders & 49 (12) & $20(13)$ & $29(12)$ & \\
\hline Immunologic disorders & $9(2)$ & $5(3)$ & $4(2)$ & \\
\hline \multicolumn{4}{|l|}{ Donor type } & 0.02 \\
\hline Matched-related & $136(33)$ & $44(25)$ & $92(39)$ & \\
\hline Mismatched-related & $16(4)$ & $6(4)$ & $10(4)$ & \\
\hline Matched-unrelated & $143(35)$ & $62(36)$ & $81(34)$ & \\
\hline Mismatched-unrelated & $32(8)$ & $18(10)$ & $14(6)$ & \\
\hline Haploidentical & $83(20)$ & $44(25)$ & 39 (17) & \\
\hline \multicolumn{4}{|l|}{ Product type } & 0.23 \\
\hline HPC-M & $319(78)$ & $130(75)$ & $189(80)$ & \\
\hline HPC-A & $91(22)$ & $44(25)$ & 47 (20) & \\
\hline \multicolumn{4}{|l|}{ CMV D/R status } & 0.14 \\
\hline Donor $^{+} /$recipient $^{+}$ & $126(31)$ & $63(36)$ & $63(27)$ & \\
\hline Donor $^{+} /$recipient $^{-}$ & 64 (16) & $24(14)$ & $40(17)$ & \\
\hline Donor $^{-} /$recipient $^{+}$ & 69 (17) & 31 (18) & 38 (16) & \\
\hline Donor $^{-} /$recipient $^{-}$ & $151(36)$ & $56(32)$ & $95(40)$ & \\
\hline \multicolumn{4}{|l|}{ TBI } & 0.15 \\
\hline Yes & $293(72)$ & $131(75)$ & $162(69)$ & \\
\hline No & 117 (28) & $43(25)$ & $74(31)$ & \\
\hline \multicolumn{4}{|l|}{ Conditioning } & 0.70 \\
\hline $\begin{array}{l}\text { Myeloablative } \\
\text { RIC }\end{array}$ & $335(82)$ & $144(83)$ & $191(81)$ & \\
\hline \multirow{2}{*}{\multicolumn{4}{|c|}{ T-cell depletion }} & $<0 \cap \cap 1$ \\
\hline $\begin{array}{l}\text {-cell depletion } \\
\text { Yes }\end{array}$ & & & & $<0.001$ \\
\hline No & $228(56)$ & $76(44)$ & $\begin{aligned} & 04(30) \\
& 152(64)\end{aligned}$ & \\
\hline \multicolumn{4}{|l|}{ Acute GVHD } & 0.009 \\
\hline Yes & $216(53)$ & $105(60)$ & $111(47)$ & \\
\hline No & $194(47)$ & $69(40)$ & 125 (53) & \\
\hline \multicolumn{4}{|l|}{ Acute GVHD grade } & $<0.0001$ \\
\hline Grade I-II & $115(28)$ & $41(24)$ & 74 (31) & \\
\hline Grade III-IV & $101(25)$ & $64(36)$ & 37 (16) & \\
\hline None & $194(47)$ & $69(40)$ & $125(53)$ & \\
\hline \multicolumn{4}{|l|}{ Chronic GVHD } & 0.06 \\
\hline Yes & $85(20)$ & $44(25)$ & $41(17)$ & \\
\hline No & $325(80)$ & $130(75)$ & $195(83)$ & \\
\hline \multicolumn{4}{|l|}{ Chronic GVHD grade } & 0.09 \\
\hline Limited & $43(10)$ & $20(11)$ & $23(10)$ & \\
\hline Extensive & 42 (10) & 24 (14) & $18(7)$ & \\
\hline None & $325(80)$ & $130(75)$ & 195 (83) & \\
\hline
\end{tabular}

Definition of abbreviations: $\mathrm{ALL}=$ acute lymphoblastic leukemia; $\mathrm{AML}=$ acute myeloid leukemia; $\mathrm{CML}=\mathrm{chronic}$ myeloid leukemia; $\mathrm{CMV} \mathrm{D} / \mathrm{R}=$ cytomegalovirus donor/recipient; GVHD = graft-versus-host disease; HPC-M/A = human progenitor cells-marrow/apheresis; MDS = myelodysplastic syndrome; $\mathrm{RIC}=$ reduced-intensity conditioning; $\mathrm{TBI}=$ total body irradiation.

Note: Unless otherwise indicated, data represent number (\%) of patients. 
Table 2. Results of pre-hematopoietic stem cell transplantation (HSCT) pulmonary function testing in 410 patients who underwent HSCT

\begin{tabular}{lcccr}
\hline Predicted Value & $\begin{array}{c}\text { FEV }_{\mathbf{1}} \\
(\boldsymbol{n}=\mathbf{4 1 0})\end{array}$ & $\begin{array}{c}\text { FVC } \\
(\boldsymbol{n}=\mathbf{4 1 0})\end{array}$ & $\begin{array}{c}\mathbf{F E F}_{\mathbf{2 5 - 7 5 \%}} \\
(\boldsymbol{n}=\mathbf{3 6 6})\end{array}$ & $\begin{array}{c}\text { TLC } \\
(\boldsymbol{n}=\mathbf{4 1 0})\end{array}$ \\
$2080 \%$ & $348(85)$ & $344(84)$ & $263(72)$ & $292(71)$ \\
$70-79 \%$ & $34(8)$ & $40(10)$ & $53(15)$ & $69(17)$ \\
$60-69 \%$ & $10(3)$ & $9(2)$ & $31(8)$ & $34(8)$ \\
$<60 \%$ & $18(4)$ & $17(4)$ & $19(5)$ & $15(4)$ \\
\hline
\end{tabular}

Definition of abbreviations: $\mathrm{FEF}_{25-75 \%}=$ forced expiratory flow at $25-75 \%$ of vital capacity. Note: Data represent number (\%) of patients.

was confirmed in all survival analyses. The cumulative incidence of an event was estimated by the Kalbfleisch-Prentice method (19), and compared using Gray's test (20). In the estimation of cumulative incidence of deaths due to pulmonary complications, deaths due to any other cause were considered competing events. Fine and Gray's regression model (21) was used to evaluate the associations between cumulative incidence, PFT variables, and covariates outlined below.

Risk factors in univariate analysis included age at transplant, sex, race, donor type, T-cell depletion, product type, TBI,
CMV D/R status, acute and chronic GVHD, and infection as a contributing cause of death. Survival status was included in pulmonary complications analysis. The parameters associated with outcomes in univariate analyses at a nominal level of 0.15 were included in their respective multivariate analyses using logistic regression, Cox proportional hazards, and Fine and Gray's regression models. All the reported $P$ values are two-sided and considered significant if less than 0.05 . Statistical analyses were performed with SAS software version 9.2 and 9.3 (SAS Institute, Cary, NC), and R version 2.13.1.

\section{Results}

\section{Pulmonary Complications}

Pulmonary complications included infectious and noninfectious complications. One hundred and forty-four (35\%) patients had infectious and $30(7 \%)$ patients had noninfectious pulmonary complications. Bacterial infections were seen in 33 (8\%) patients, equally distributed among grampositive and gram-negative infections. Mycoplasma, Pseudomonas, Klebsiella, and Stenotrophomonas species were the most common bacterial pathogens. Fungal infections were seen in $41(10 \%)$ patients and were equally distributed among yeast and molds (19 patients each). Candida and Aspergillus species were the most common pathogens. Viral infections were seen in $91(22 \%)$ patients. Influenza (28 patients), parainfluenza (21 patients), and respiratory syncytial virus (4 patients) were the most common pathogens detected. The total number of patients with specific infections $0-30 / 31-100 / 101-730 />730$ were as follows: fungal, $41(8 / 11 / 22 / 0)$; grampositive bacteria, $18(3 / 7 / 7 / 1)$; gramnegative bacteria, $15(0 / 5 / 9 / 1)$; respiratory

Table 3. Results of pre-hematopoietic stem cell transplantation pulmonary function testing in all patients and those with or without pulmonary complications

\begin{tabular}{|c|c|c|c|c|}
\hline Characteristic & $\begin{array}{l}\text { All Patients } \\
(n=410)\end{array}$ & $\begin{array}{l}\text { Patients with Pulmonary } \\
\text { Complications } \\
(n=174)\end{array}$ & $\begin{array}{l}\text { Patients without Pulmonary } \\
\text { Complications } \\
\text { (n=236) }\end{array}$ & $P$ Value \\
\hline FVC & $0.96(0.17)$ & $0.95(0.17)$ & $0.97(0.17)$ & 0.60 \\
\hline $\mathrm{FVC}_{\mathrm{GLI}-2012}$ & $0.94(0.17)$ & $0.93(0.17)$ & $0.94(0.17)$ & 0.68 \\
\hline $\mathrm{FVC}_{\mathrm{GLI}-2012} \mathrm{z}$-score & $-0.54(1.48)$ & $-0.61(1.48)$ & $-0.49(1.47)$ & 0.66 \\
\hline $\mathrm{FEV}_{1}$ & $0.95(0.17)$ & $0.94(0.18)$ & $0.96(0.16)$ & 0.55 \\
\hline $\mathrm{FEV}_{1} \mathrm{GLI}-2012$ & $0.92(0.17)$ & $0.91(0.17)$ & $0.93(0.16)$ & 0.62 \\
\hline $\mathrm{FEV}_{1} \mathrm{GLI}-2012$ z-score & $-0.64(1.37)$ & $-0.71(1.43)$ & $-0.59(1.32)$ & 0.61 \\
\hline $\mathrm{FEV}_{1} / \mathrm{FVC}$ & 0.99 (0.08) & 0.99 (0.08) & $0.99(0.08)$ & 0.21 \\
\hline $\mathrm{FEV}_{1} / \mathrm{FVC}_{\mathrm{GLI}-2012}$ & $0.98(0.08)$ & $0.98(0.08)$ & $0.98(0.08)$ & 0.18 \\
\hline $\mathrm{FEV}_{1} / \mathrm{FVC}$ z-score & $-0.16(1.09)$ & $-0.22(1.07)$ & $-0.12(1.11)$ & 0.16 \\
\hline $\mathrm{FEF}_{25-75 \%}$ & $0.94(0.25)$ & $0.91(0.23)$ & $0.97(0.27)$ & 0.04 \\
\hline $\mathrm{FEF}_{25-75 \% \text { GLI-2012 }}$ & $0.90(0.25)$ & $0.86(0.22)$ & $0.92(0.27)$ & 0.03 \\
\hline $\mathrm{FEF}_{25-75 \%} \mathrm{z}$-score & $-0.53(1.13)$ & $-0.69(1.06)$ & $-0.42(1.17)$ & 0.03 \\
\hline TLC & $0.91(0.18)$ & $0.90(0.19)$ & $0.92(0.17)$ & 0.29 \\
\hline $\mathrm{RV}$ & $0.98(0.45)$ & $0.97(0.48)$ & $0.98(0.42)$ & 0.69 \\
\hline $\mathrm{DL}_{\mathrm{CO}}$ & $0.82(0.19)$ & $0.82(0.18)$ & $0.83(0.20)$ & 0.84 \\
\hline FRC & $0.88(0.25)$ & $0.86(0.26)$ & $0.89(0.25)$ & 0.16 \\
\hline $\begin{array}{l}\text { OLD } \\
\text { Present }\end{array}$ & $28(7)$ & & & 0.17 \\
\hline Absent & $28(7)$ & $8(5)$ & 20 (8) & \\
\hline RLD & 382 (93) & $166(95)$ & $216(92)$ & 0.23 \\
\hline Present & $118(29)$ & $56(32)$ & $62(26)$ & \\
\hline Absent & $292(71)$ & $118(68)$ & $174(74)$ & \\
\hline
\end{tabular}

Definition of abbreviations: $\mathrm{D} \mathrm{L}_{\mathrm{CO}}=$ single-breath diffusing capacity for carbon monoxide, in $\mathrm{ml} / \mathrm{minute} / \mathrm{mm} \mathrm{Hg}$; $\mathrm{FEF}_{25-75 \%}=$ forced expiratory flow during the midportion of the forced vital capacity, in liters/second; FVC GLI-2012 = forced vital capacity as calculated by the Global Lungs Initiative 2012, in liters; OLD = obstructive lung disease; RLD = restrictive lung disease; $R V=$ residual volume, in liters.

Note: Data represent mean (SD) of pulmonary function tests or number (\%) of patients. 
viruses, 91 (17/18/49/7); and 1 patient with toxoplasmosis 101-730 days post-HSCT.

Among the $30(7 \%)$ patients who had noninfectious pulmonary complications, diffuse alveolar hemorrhage was diagnosed in 5 , COP in 6 , and BOS in 5 patients. The remaining 14 patients were diagnosed as having interstitial lung disease confirmed by autopsy.

Characteristics of all patients combined, and those with or without pulmonary complications, are presented in Table 1. Donor type was significant $(P=0.02)$; in particular, children who underwent a haploidentical transplant were more likely than those who underwent a matched-related transplant to have pulmonary complications $(P=0.01$; odds ratio $[\mathrm{OR}], 0.4 ; 95 \%$ confidence interval [CI], 0.24-0.74). Patients with T-celldepleted grafts $(P<0.001)$, and acute GVHD $(P=0.009)$, had more pulmonary complications (Table 1).

\section{Pulmonary Function Tests and Pulmonary Complications}

The majority of patients had pretransplant spirometry and lung volume indices equal to or greater than $70 \%$ predicted (Table 2 ). $\mathrm{DL}_{\mathrm{CO}}$ was equal to or greater than $50 \%$ in $373(91 \%)$ patients, less than $50 \%$ in 13 (3\%) patients, and not available in $24(6 \%)$ patients. The majority of patients (271; $66 \%)$ did not have either OLD or RLD. Twenty-one (5\%) patients had OLD, 111 (27\%) patients had RLD, and 7 (2\%) patients had both OLD and RLD. Of the 28 patients who had OLD, obstruction was mild in 21 patients, moderate in 2 , severe in 4 , and very severe in 1 patient. The majority of patients $(209 ; 51 \%)$ were in LFS category I, $168(41 \%)$ were in LFS category II, and $33(8 \%)$ were in LFS category III. There were no patients in LFS category IV.

Patients with pulmonary complications had significantly lower $\mathrm{FEF}_{25-75 \%}(P=0.04)$, $\mathrm{FEF}_{25-75 \% \text { GLI-2012 }}(P=0.03)$, and standard deviation $(\mathrm{z})$ scores for $\mathrm{FEF}_{25-75 \%}(P=0.03$; Table 3). Logistic regression analysis showed that each unit decrease in $\mathrm{FEF}_{25}$ $75 \%$ resulted in a threefold increased risk of developing pulmonary complications $(P=$ 0.02 ; Table 4$)$. Similar results were obtained when using the GLI-2012 predicted equations. T-cell depletion $(P=0.001)$, acute grade $3-4$ GVHD $(P=0.008)$, chronic GVHD $(P=0.01)$, and infection $(P=0.006)$ increased risk for pulmonary complications (Table 4).

Table 4. Transplant variables significant on logistic regression analysis of hematopoietic stem cell transplantation patients with or without pulmonary complications

\begin{tabular}{|c|c|c|c|c|}
\hline Characteristic & $P$ Value & OR & $95 \% \mathrm{Cl}$ & Reference \\
\hline \multicolumn{5}{|c|}{ Univariate Analysis ${ }^{\star}$} \\
\hline CMV-positive donor & 0.03 & 1.54 & $1.04-2.29$ & CMV-neg \\
\hline T-cell depletion & $<0.0001$ & 2.33 & $1.56-3.48$ & T-replete \\
\hline Acute grade $3-4$ GVHD & $<0.0001$ & 3.05 & $1.75-5.31$ & Others \\
\hline Chronic GVHD & 0.05 & 1.61 & $1.00-2.60$ & None \\
\hline Infection & 0.0002 & 4.78 & $2.10-10.88$ & None \\
\hline $\mathrm{FEF}_{25-75 \%}$ & 0.03 & 2.61 & $1.10-6.20$ & \\
\hline \multicolumn{5}{|c|}{ Multivariate Analysis ${ }^{\dagger}$} \\
\hline T-cell depletion & 0.001 & 0.33 & $0.16-0.66$ & T-replete \\
\hline Acute grade $3-4$ GVHD & 0.008 & 0.45 & $0.25-0.85$ & Others \\
\hline Chronic GVHD & 0.01 & 0.46 & $0.25-0.85$ & None \\
\hline Infection & 0.006 & 0.20 & $0.06-0.63$ & None \\
\hline $\mathrm{FEF}_{25-75 \%}$ & 0.02 & 3.21 & $1.16-8.86$ & \\
\hline \multicolumn{5}{|c|}{ Multivariate Analysis Using GLI-2012 Predicted Values } \\
\hline T-cell depletion & 0.002 & 0.36 & $0.19-0.70$ & T-replete \\
\hline Acute grade $3-4$ GVHD & 0.004 & 0.45 & $0.26-0.78$ & Others \\
\hline Chronic GVHD & 0.04 & 0.55 & $0.31-0.97$ & None \\
\hline Infection & 0.005 & 0.23 & $0.08-0.65$ & None \\
\hline FEF $_{25-75 \%}$ GLI-2012 & 0.01 & 3.32 & $1.29-8.50$ & \\
\hline
\end{tabular}

Definition of abbreviations: $\mathrm{Cl}=$ confidence interval; $\mathrm{CMV}=$ cytomegalovirus; $\mathrm{FEF}_{25-75 \%} \mathrm{GLI}-2012=$ forced expiratory flow during the midportion of the forced vital capacity as calculated by the Global Lungs Initiative 2012, in liters/second; GVHD = graft-versus-host disease; neg = negative; OR = odds ratio.

${ }^{*}$ For univariate analysis, the probability modeled for CMV donor status, T-cell depletion, acute GVHD grade 3-4, chronic GVHD, and infection as the contributing cause of death was patients with pulmonary complications (reference group is patients with no pulmonary complications). However, for variables $\mathrm{FEF}_{25-75 \%}$ and $\mathrm{FEF}_{25-75 \%}$ GLI-2012, expressed in liters/second, the probability modeled was patients with no pulmonary complications (reference group is patients with pulmonary complications). ${ }^{t}$ For multivariate analysis, the probability modeled was patients with no pulmonary complications for all the variables (reference group is patients with pulmonary complications).

Of 174 patients who developed pulmonary complications, 169 (97\%) had $\mathrm{FEF}_{25-75 \%}$ GLI-2012 less than LLN. In comparison, there were 236 patients with no pulmonary complications, and 218 (92\%) had $\mathrm{FEF}_{25-75 \%}$ GLI-2012 less than LLN $(P=0.04$; OR, 2.80; 95\% CI, 1.01-7.67).

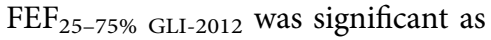
a predictor of pulmonary complications on univariate $(P=0.03$; OR, 2.60; 95\% CI, 1.10 $6.13)$ and multivariate analysis $(P=0.02$; $\mathrm{OR}$, 3.11; 95\% CI, 1.15-8.40) when pulmonary infections were considered independently. Of all the pretransplant PFTs, only $\mathrm{FEF}_{25-75 \%}$ was significant. When noninfectious complications were considered independently $\mathrm{FEF}_{25-75 \%}$ was a significant predictor of pulmonary complications on univariate $(P=0.04$; OR, 6.02; 95\% CI, 1.04-34.71) but not multivariate analysis.

Patients with acute lymphoblastic leukemia and lymphoma received steroids as part of therapy for their underlying disease pre-HSCT. These patients did not have a decreased risk for pulmonary complications $(P=0.5)$. Patients with acute GVHD, chronic GVHD, BOS, and COP received steroids as part of therapy postHSCT. These patients had an increased risk for pulmonary complications $(P=0.005$; OR, 1.80; 95\% CI, 1.16-2.71).

Patients with pulmonary complications had a 2.8-fold increased risk of mortality $(P<0.0001)$. Cumulative incidence was then estimated for deaths due to pulmonary complications $(n=41)$. Residual volume less than $50 \%$ versus at least $50 \%$ or more $(P=0.01$; Figure 1A), FRC less than $50 \%$ versus at least $50 \%$ or more $(P=0.01$; Figure 1B), TLC less than $50 \%$ versus at least $50 \%$ or more $(P<0.001$; Figure $1 C)$, age $(P=0.06)$, donor type $(P=0.01)$, apheresis product $(P=0.02)$, CMV donor status $(P=0.06)$, acute GVHD $(P=0.007)$, and T-cell depletion $(P=0.0003)$ were significant on univariate analysis.

Multivariate analysis revealed that RV less than $50 \%$ versus at least $50 \%$ or more $(P=0.007)$, FRC less than $50 \%$ versus at least $50 \%$ or more $(P=0.005)$, TLC less 

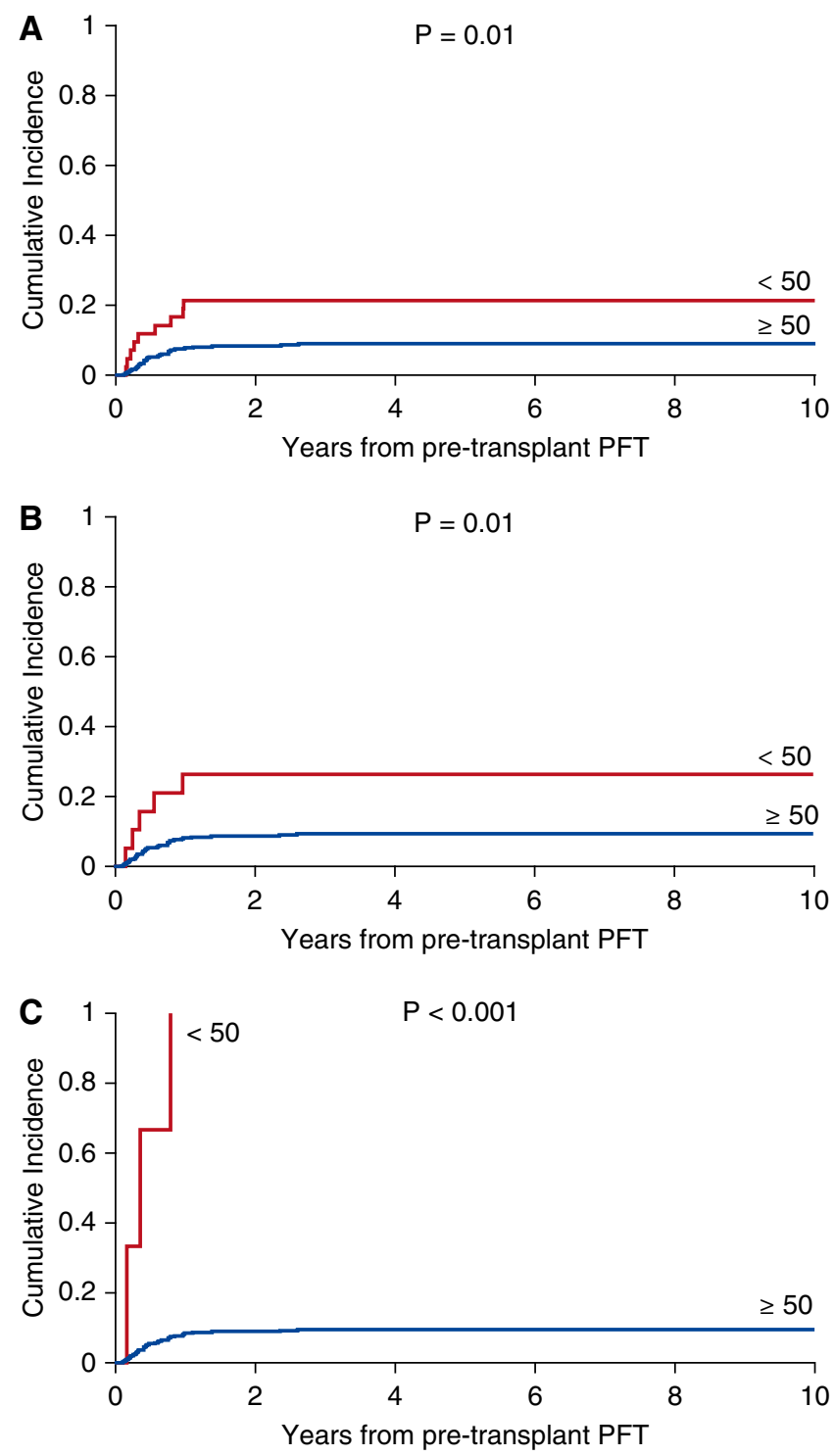

Figure 1. (A) Cumulative incidence of deaths due to pulmonary complications over the years of follow-up from pretransplant pulmonary function testing (PFT) based on residual volume (RV). RV in liters was categorized as less than $50 \%$ versus equal to or greater than $50 \%$ predicted. $(B)$ Cumulative incidence of deaths due to pulmonary complications over the years of follow-up from pretransplant PFT based on FRC. FRC in liters was categorized as less than $50 \%$ versus equal to or greater than $50 \%$ predicted. (C) Cumulative incidence of deaths due to pulmonary complications over the years of follow-up from pretransplant PFT based on TLC. TLC in liters was categorized as less than $50 \%$ versus equal to or greater than $50 \%$ predicted.

than $50 \%$ versus at least $50 \%$ or more $(P=0.0002)$, and T-cell depletion $(P=0.01$ calculated with RV as the PFT outcome variable) predicted deaths due to pulmonary complications.

\section{Overall Survival}

Forty-one patients died of pulmonary complications; 166 patients died of other causes. Univariate analysis revealed $\mathrm{FEV}_{1}$ less than $50 \%(P=0.02), \mathrm{FEV}_{1 \mathrm{GLI}-2012}$ less than 50\% $(P=0.03), \mathrm{FEV}_{1}(P<0.0001$; Figure $2 \mathrm{~A}), \mathrm{FEV}_{1 \text { GLI-2012 }}(P=0.0002), \mathrm{FVC}$ $(P=0.0001$; Figure $2 \mathrm{~B}), \mathrm{FVC}_{\mathrm{GLI}-2012}(P=$ $0.0002)$, TLC $(P=0.0002$; Figure $2 \mathrm{C})$, RV less than $50 \%(P=0.02)$, RLD $(P=0.007)$, and LFS category $(P=0.03$; Figure $2 D)$ to be associated with poor survival, as were age $(P=0.006)$, donor type $(P=0.0007)$, apheresis product $(P=0.002)$, T-cell depletion $(P=$ $0.001)$, acute GVHD grade $3-4(P<0.001)$, chronic GVHD $(P=0.01)$, and TBI $(P=0.08)$.
Multivariate analysis showed that $\mathrm{FEV}_{1}$ less than $70 \%$ predicted $(P=0.0005)$, FVC less than $70 \%$ predicted $(P=0.0005)$, TLC less than $60 \%$ predicted $(P<0.0001)$, RV less than $50 \%(P=0.01)$, and the presence of $\operatorname{RLD}(P=0.01)$ were associated with poor survival. Similar results for $\mathrm{FEV}_{1}$ and FVC were obtained when using the GLI2012 predicted equations (Table 5). Older age $(P=0.001)$, acute GVHD $(P=0.04)$, and TBI-based conditioning $(P=0.004)$ were associated with worse survival, whereas chronic GVHD $(P=0.0005)$ was associated with improved survival (Table 5).

\section{Discussion}

Pretransplant pulmonary function testing is routinely performed as a baseline reference, in anticipation of potential pulmonary complications post-HSCT, which contribute significantly to the morbidity and mortality from this procedure $(1,3,22)$. However, the predictive value of this test in children and adults is controversial. Horak and colleagues recognized reduced $\mathrm{FEV}_{1}$ to be a strong risk factor for development of $\mathrm{CMV}$-associated interstitial pneumonia in HSCT recipients (23). It is possible that factors predisposing to lung damage and altering lung function pretransplant may alter the interplay between infectious and immunologic factors after transplant, resulting in increased risk of pulmonary complications. Pulmonary infections often accompany noninfectious pulmonary complications (24). The predictive value of pretransplant PFT for infectious and noninfectious pulmonary complications, and mortality from these complications, have not been well studied in children.

Children with pulmonary complications in our study had significantly lower pretransplant $\mathrm{FEF}_{25-75 \%}$ as analyzed both by Wang and colleagues (5) and Hankinson and colleagues (6), and with the GLI-2012 equations (7). This is a novel observation. The mild airway obstruction may make these children more susceptible to infections post-HSCT, resulting in worsening obstruction and more infections. Lower respiratory tract infections with parainfluenza and respiratory syncytial virus have been associated with late airflow decline after transplant (25). Longitudinal analysis of HSCT survivors in a previous study at our institution showed a gradual decline in $\mathrm{FEF}_{25-75 \%}$ post-transplant, 
Table 5. Transplant variables significant for overall survival on multivariate analysis

\begin{tabular}{|c|c|c|c|c|c|c|c|}
\hline \multicolumn{3}{|l|}{ Characteristic* } & $P$ Value & \multicolumn{3}{|c|}{ HR } & $95 \% \mathrm{Cl}$ \\
\hline \multicolumn{3}{|c|}{$\begin{array}{l}\text { Age } \\
\text { Acute GVHD (ref none) } \\
\text { Chronic GVHD (ref none) } \\
\text { TBI (ref none) }\end{array}$} & $\begin{array}{l}0.001 \\
0.04 \\
0.0005 \\
0.004\end{array}$ & \multicolumn{3}{|c|}{$\begin{array}{l}1.06 \\
1.38 \\
0.50 \\
1.70\end{array}$} & $\begin{array}{l}1.02-1.10 \\
1.01-1.83 \\
0.34-0.73 \\
1.18-2.46\end{array}$ \\
\hline PFT & $P$ Value & HR & $95 \% \mathrm{Cl}$ & $\mathrm{PFT}_{\mathrm{GLI}-2012}$ & $P$ Value & HR & $95 \% \mathrm{Cl}$ \\
\hline $\begin{array}{l}\mathrm{FEV}_{1}(\mathrm{ref} \geqslant 80 \% ; \mathrm{L}) \\
<60 \% \\
60-69 \% \\
70-79 \% \\
\text { FVC (ref } \geqslant 80 \% ; \mathrm{L}) \\
<60 \% \\
60-69 \% \\
70-79 \% \\
\text { TLC (ref } \geqslant 80 \% ; \text { L) } \\
<60 \% \\
60-69 \% \\
70-79 \%\end{array}$ & $\begin{array}{l}0.0005 \\
0.01 \\
0.0004 \\
0.92 \\
0.0005 \\
0.001 \\
0.005 \\
0.40 \\
<0.0001 \\
<0.0001 \\
0.26 \\
0.24\end{array}$ & $\begin{array}{l}2.61 \\
2.92 \\
1.22 \\
\\
4.78 \\
1.35 \\
1.25 \\
\end{array}$ & $\begin{array}{l}1.18-3.66 \\
1.79-7.77 \\
0.56-1.67 \\
\\
1.46-4.64 \\
1.37-6.20 \\
0.76-1.96 \\
\\
2.56-8.93 \\
0.79-2.30 \\
0.86-1.82\end{array}$ & $\mathrm{FVC}_{\mathrm{GLI}-2012} ; \mathrm{L}$ & $\begin{array}{l}0.004 \\
0.0004 \\
0.38 \\
0.89 \\
0.0008 \\
0.005 \\
0.002 \\
0.77\end{array}$ & $\begin{array}{l}2.59 \\
1.39 \\
1.03 \\
\\
2.27 \\
2.75 \\
0.93\end{array}$ & $\begin{array}{l}1.27-4.05 \\
1.45-5.23 \\
0.59-1.48\end{array}$ \\
\hline \multicolumn{2}{|l|}{ PFT } & \multicolumn{2}{|r|}{$P$ Value } & \multicolumn{2}{|l|}{ HR } & & $95 \% \mathrm{Cl}$ \\
\hline $\begin{array}{l}\text { RV (ref } \geqslant 50 \% ; \text { L) } \\
<50 \% \\
\text { RLD (ref none) } \\
\text { LFS (ref category I) } \\
\text { Category II } \\
\text { Category III }\end{array}$ & & & $\begin{array}{l}0.01 \\
0.01 \\
0.10 \\
0.43 \\
0.03\end{array}$ & $\begin{array}{l}1.69 \\
1.48\end{array}$ & & & $\begin{array}{l}1.11-2.56 \\
1.08-2.03\end{array}$ \\
\hline
\end{tabular}

Definition of abbreviations: $\mathrm{Cl}=$ confidence interval; GVHD = graft-versus-host disease; $\mathrm{HR}=$ hazard ratio; LFS = Lung Function Score; PFT = pulmonary function test; PFT $\mathrm{GLI}_{2012}=$ pulmonary function test as calculated according to Global Lungs Initiative 2012; ref = reference; RLD = restrictive lung disease; $\mathrm{RV}=$ residual volume; $\mathrm{TBI}=$ total body irradiation.

*Values for age/acute GVHD/TBI calculated for FVC.

${ }^{\dagger}$ Category I, normal; category II, mildly abnormal; category III, moderately abnormal.

particularly in older patients (26). The observation of similar conclusions when using the GLI-2012 and conventional equations in the current study underscores the good agreement for predicted values for spirometric indices from GLI-2012 equations (7) and equations in Wang and colleagues (5) and Hankinson and colleagues (6) within ethnic groups (27).

Decline in $\mathrm{FEF}_{25-75 \%}$ has been reported with lung irradiation boosts in children with solid tumors (28), perhaps as a result of pulmonary fibrosis and impaired peripheral airway development. Chemotherapeutic agents such as bleomycin, cyclophosphamide, busulfan, and nitrosoureas have been associated with late-onset pulmonary fibrosis (29). These insults may have led to irreversible steroidunresponsive airway obstruction preHSCT. Further, the vast majority of our patients received busulfan or total body irradiation-based myeloablative conditioning. Damage to the airways as a result of conditioning, alloreactive responses secondary to GVHD, recurrent aspiration due to oral and upper gastrointestinal GVHD, increased risk of infections due to immunosuppressants used for treatment of GVHD, infections due to airway obstruction, and small airway size may have further increased airway obstruction and pulmonary complications. The contribution of GVHD to pulmonary complications was noted both on logistic regression analysis and when examining a subset of patients who received steroid therapy for treatment of GVHD.

An association between acute GVHD, chronic GVHD and the subsequent development of COP has previously been observed (30). Prior occurrence of acute GVHD has also been noted as a risk factor for BOS (31). In the study by Efrati and colleagues, patients who underwent HSCT without GVHD had no reduction in lung function; however, of the 10 patients who had GVHD, 7 developed BOS (2). In other reports, patients receiving matchedunrelated donor HSCT who had chronic GVHD were more likely to develop noninfectious pulmonary complications (32). T-cell depletion was also associated with an increased risk of developing pulmonary complications in our study. This may be related to poor T-cell reconstitution and severe $\mathrm{CD} 4^{+}$ lymphopenia associated with an increased risk of respiratory infections (33).

Gram-positive and gram-negative, yeast and mold, and parainfluenza and influenza respiratory viral infections were equally common, and occurred after a similar time frame compared with systemic infections in children undergoing allogeneic HSCT (34).

The current study shows an almost threefold increased risk for mortality from pulmonary complications. Previous studies have shown similar results (3). Pretransplant RLD predicted poor survival due to pulmonary complications. This is a novel finding and has not been previously reported in children. Causes of RLD pretransplant include previous chemotherapy, particularly with alkylating agents; irradiation; and infections (29). Approximately one-quarter of our patients had RLD pretransplant. The preparative regimen, GVHD, and posttransplant infections may cause further lung parenchymal damage and alveolar volume loss. In other studies approximately one-third of patients had RLD on PFT performed a median of 10 years after $\operatorname{HCT}(35,36)$, stressing the need for long-term follow-up.

Lower pretransplant $\mathrm{FEV}_{1}$ and FVC were associated with poorer OS. These indices increased risk of early respiratory failure both in pediatric (3) and adult $(37,38)$ studies. LFS is a summation of $\mathrm{FEV}_{1}$ and $\mathrm{DL}_{\mathrm{CO}}$. DL $\mathrm{L}_{\mathrm{CO}}$ was recognized to be a risk factor for mortality in pediatric (4) and adult (18, 39) studies. Moderately abnormal LFS was a significant predictor of poor survival in our study. The presence of RLD pretransplant was significantly associated with an increased risk for early respiratory failure (40), and mortality after RIC HSCT in adults (41). We have shown that RLD pretransplant predicted poorer OS in children, an observation not reported previously in this age group.

In our study children who were older, had acute GVHD, and received TBI had poorer OS. Older age at HSCT was shown in a previous study at our institution to be associated with significant declines in 

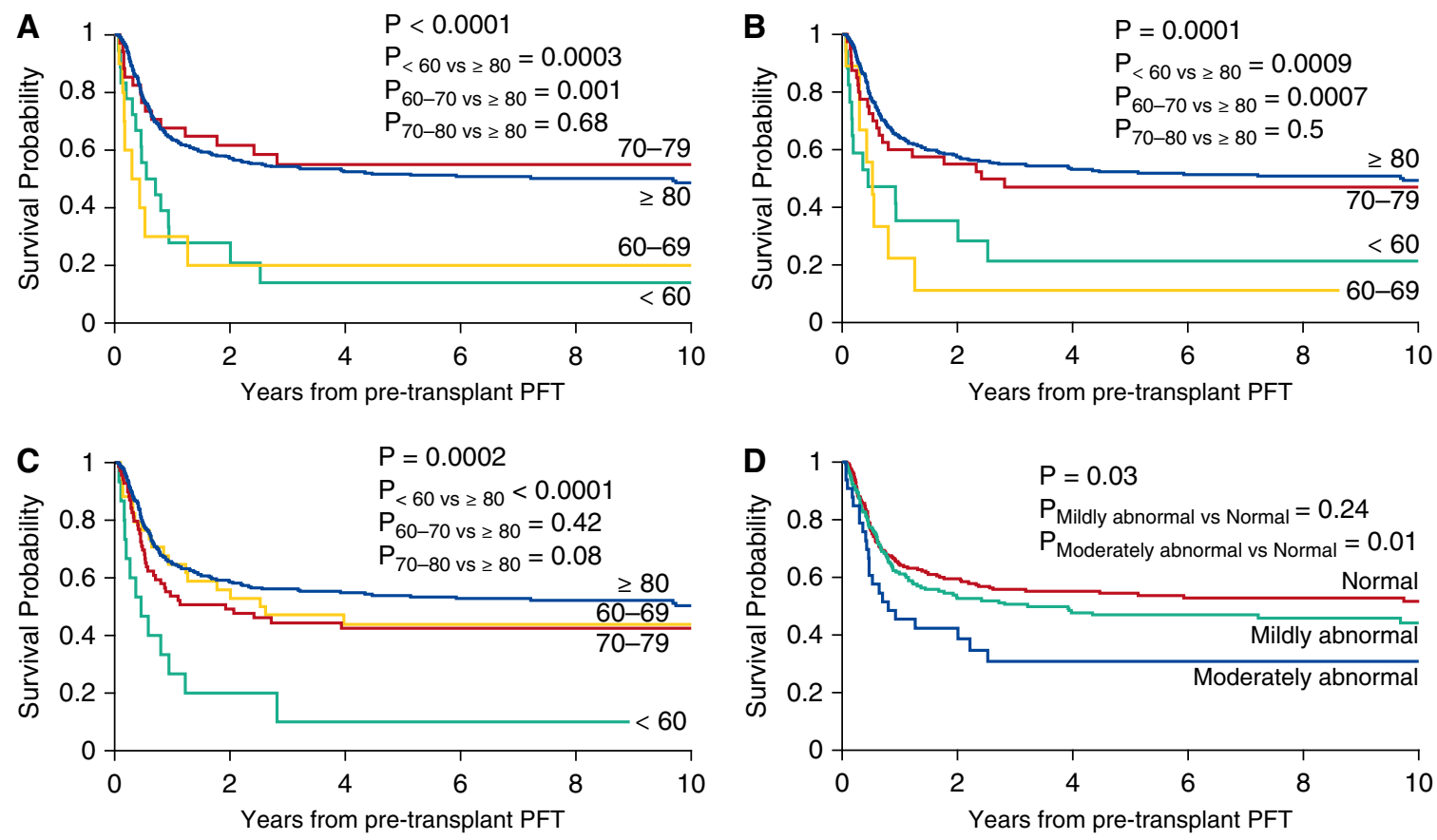

Figure 2. (A) Probability of overall survival in years from pretransplant pulmonary function testing (PFT) based on FEV 1 . FEV 1 in liters was categorized as less than 60\%,60-69\%, 70-79\% and equal to or greater than $80 \%$ predicted. (B) Probability of overall survival in years from pretransplant PFT based on FVC. FVC in liters was categorized as less than 60\%, 60-69\%, 70-79\% and equal to or greater than $80 \%$ predicted. (C) Probability of overall survival in years from pretransplant PFT based on TLC. TLC in liters was categorized as less than 60\%, 60-69\%, 70-79\%, and equal to or greater than $80 \%$ predicted. (D) Probability of overall survival in years from pretransplant PFT based on Lung Function Score (LFS). LFS was categorized as normal (category I), mildly abnormal (category II), and moderately abnormal (category III).

$\mathrm{FEV}_{1} / \mathrm{FVC}$, higher RV/TLC, and worsening of $\mathrm{DL}_{\mathrm{CO}}$ posttransplant (26). Crawford and colleagues reported an association between acute GVHD and pulmonary injury (42).

However, chronic GVHD was associated with improved survival in our study perhaps as a result of decreased relapse (43), the predominant cause of mortality posttransplant. Because only one-half of the patients had extensive GVHD, the survival benefit may have favored increased nonrelapse mortality due to chronic GVHD (44). Adults receiving myeloablative conditioning had much greater declines in $\mathrm{FEV}_{1}$ compared with those receiving nonmyeloablative conditioning, with a higher mortality risk especially if the pretransplant $\mathrm{FEV}_{1}$ was less than $60 \%$ (45). In adults with combined ventilation/diffusing capacity deficits pretransplant, reduction in lung TBI dose improved survival (46).

The strengths of our study include a large retrospective cohort of children with a long follow-up. Predicted spirometry values were calculated using both conventional and the more recent GLI-2012 indices, reaching similar conclusions derived from both predicted equations. PFTs were performed by the same instrumental method for the duration of study, for the most part performed by the same technician. Pulmonary complications were used as an outcome measure rather than OS alone, which is confounded by mortality due to relapse. The study was, however, limited by being retrospective. Causes of abnormal lung function pretransplant were not determined. This may be better addressed in a future prospective study. Children less than 6 years of age were excluded. Assessment of pulmonary function in this age group should be considered for future studies.

The value of $\mathrm{FEF}_{25-75 \%}$ in children remains controversial (47). Reports in recipients of lung transplantation have shown that $\mathrm{FEF}_{25-75 \%}$ is more sensitive than $\mathrm{FEV}_{1}$ for early detection of BOS $(48,49)$. Further studies in children post-HSCT are needed to confirm our findings.

In summary, our study shows a novel association between pretransplant $\mathrm{FEF}_{25-75 \%}$ and pulmonary complications. Pulmonary complications resulted in an almost threefold increased risk of mortality. Pretransplant RLD predicted poorer survival due to pulmonary complications. Lower pretransplant $\mathrm{FEV}_{1}$ and $\mathrm{FVC}$, higher LFS, and RLD were associated with poor OS. Thus, abnormalities in pretransplant PFT may warrant consideration of reducedintensity conditioning without the use of TBI and busulfan, based on disease status and donor availability, and use of lung shielding when TBI is necessary. Prevention of GVHD may substantially reduce the risk of pulmonary complications. Close follow-up of small airway obstruction posttransplant with assessment of bronchodilator responsiveness, and strategies to preserve lung function, will be important as this population of survivors continues to age.

Author disclosures are available with the text of this article at www.atsjournals.org.

Acknowledgment: The authors thank Paul W. Mackert (Pulmonary Function Laboratory at St. Jude Children's Research Hospital, Memphis, TN) for performing most of the pulmonary function testing, and for assistance in data collection. 


\section{References}

1 Eikenberry M, Bartakova H, Defor T, Haddad IY, Ramsay NKC, Blazar BR, Milla CE, Cornfield DN. Natural history of pulmonary complications in children after bone marrow transplantation. Biol Blood Marrow Transplant 2005;11:56-64.

2 Efrati O, Toren A, Duskin H, Modan-Moses D, Bielorai B, Goldstein G, Churi C, Vilozni D. Pulmonary function studies in children treated by chemoradiotherapy and stem cell transplantation. Pediatr Blood Cancer 2008;51:684-688.

3 Kaya Z, Weiner DJ, Yilmaz D, Rowan J, Goyal RK. Lung function, pulmonary complications, and mortality after allogeneic blood and marrow transplantation in children. Biol Blood Marrow Transplant 2009;15:817-826.

4 Ginsberg JP, Aplenc R, McDonough J, Bethel J, Doyle J, Weiner DJ. Pre-transplant lung function is predictive of survival following pediatric bone marrow transplantation. Pediatr Blood Cancer 2010; 54:454-460.

5 Wang X, Dockery DW, Wypij D, Fay ME, Ferris BG Jr. Pulmonary function between 6 and 18 years of age. Pediatr Pulmonol 1993;15: 75-88.

6 Hankinson JL, Odencrantz JR, Fedan KB. Spirometric reference values from a sample of the general U.S. population. Am J Respir Crit Care Med 1999;159:179-187.

7 Quanjer PH, Stanojevic S, Cole TJ, Baur X, Hall GL, Culver BH, Enright PL, Hankinson JL, Ip MSM, Zheng J, et al.; ERS Global Lung Function Initiative. Multi-ethnic reference values for spirometry for the 3-95 yr age range: the Global Lung Function 2012 equations. Eur Respir J 2012;40:1324-1343.

8 Leung WH, Turner V, Richardson SL, Benaim E, Hale G, Horwitz EM, Woodard P, Bowman LC. Effect of HLA class I or class II incompatibility in pediatric marrow transplantation from unrelated and related donors. Hum Immunol 2001;62:399-407.

9 Leung W, Campana D, Yang J, Pei D, Coustan-Smith E, Gan K, Rubnitz JE, Sandlund JT, Ribeiro RC, Srinivasan A, et al. High success rate of hematopoietic cell transplantation regardless of donor source in children with very high-risk leukemia. Blood 2011;118:223-230.

10 Przepiorka D, Weisdorf D, Martin P, Klingemann HG, Beatty P, Hows J, Thomas ED. 1994 consensus conference on acute GVHD grading. Bone Marrow Transplant 1995;15:825-828.

11 Michelson PH, Goyal R, Kurland G. Pulmonary complications of haematopoietic cell transplantation in children. Paediatr Respir Rev 2007;8:46-61.

12 Gower WA, Collaco JM, Mogayzel PJ Jr. Pulmonary dysfunction in pediatric hematopoietic stem cell transplant patients: non-infectious and long-term complications. Pediatr Blood Cancer 2007;49: 225-233.

13 Miller MR, Crapo R, Hankinson J, Brusasco V, Burgos F, Casaburi R, Coates A, Enright P, van der Grinten CP, Gustafsson P, et al.; ATS/ ERS Task Force. General considerations for lung function testing. Eur Respir J 2005;26:153-161.

14 Stocks J, Quanjer PH. Reference values for residual volume, functional residual capacity and total lung capacity [ATS Workshop on Lung Volume Measurements; official statement of the European Respiratory Society]. Eur Respir J 1995;8:492-506.

15 Kim YJ, Hall GL, Christoph K, Tabbey R, Yu Z, Tepper RS, Eigen H. Pulmonary diffusing capacity in healthy Caucasian children. Pediatr Pulmonol 2012;47:469-475.

16 Paoletti P, Viegi G, Pistelli G, Di Pede F, Fazzi P, Polato R, Saetta M, Zambon R, Carli G, Giuntini C, et al. Reference equations for the single-breath diffusing capacity: a cross-sectional analysis and effect of body size and age. Am Rev Respir Dis 1985;132:806-813.

17 Quanjer PH, Pretto JJ, Brazzale DJ, Boros PW. Grading the severity of airways obstruction: new wine in new bottles. Eur Respir J 2014;43: 505-512.

18 Parimon T, Madtes DK, Au DH, Clark JG, Chien JW. Pretransplant lung function, respiratory failure, and mortality after stem cell transplantation. Am J Respir Crit Care Med 2005;172:384-390.

19 Prentice RL, Kalbfleisch JD, Peterson AV Jr, Flournoy N, Farewell VT, Breslow NE. The analysis of failure times in the presence of competing risks. Biometrics 1978;34:541-554.
20 Gray RJ. A class of $K$-sample tests for comparing the cumulative incidence of a competing risk. Ann Stat 1988;16:1141-1154.

21 Fine JP, Gray RJ. A proportional hazards model for the subdistribution of a competing risk. JASA 1999;94:496-509.

22 Johnson FL, Stokes DC, Ruggiero M, Dalla-Pozza L, Callihan TR. Chronic obstructive airways disease after bone marrow transplantation. J Pediatr 1984;105:370-376.

23 Horak DA, Schmidt GM, Zaia JA, Niland JC, Ahn C, Forman SJ. Pretransplant pulmonary function predicts cytomegalovirusassociated interstitial pneumonia following bone marrow transplantation. Chest 1992;102:1484-1490.

24 Sharma S, Nadrous HF, Peters SG, Tefferi A, Litzow MR, Aubry MC, Afessa B. Pulmonary complications in adult blood and marrow transplant recipients: autopsy findings. Chest 2005;128: 1385-1392.

25 Erard V, Chien JW, Kim HW, Nichols WG, Flowers ME, Martin PJ, Corey L, Boeckh M. Airflow decline after myeloablative allogeneic hematopoietic cell transplantation: the role of community respiratory viruses. J Infect Dis 2006;193:1619-1625.

26 Inaba H, Yang J, Pan J, Stokes DC, Krasin MJ, Srinivasan A, Hartford CM, Pui CH, Leung W. Pulmonary dysfunction in survivors of childhood hematologic malignancies after allogeneic hematopoietic stem cell transplantation. Cancer 2010;116: 2020-2030.

27 Quanjer PH, Weiner DJ. Interpretative consequences of adopting the Global Lungs 2012 reference equations for spirometry for children and adolescents. Pediatr Pulmonol 2014;49:118-125.

28 Motosue MS, Zhu L, Srivastava K, Stokes DC, Hudson MM, McPherson V, Srinivasan S, Krasin MJ, Green DM, Spunt SL, et al. Pulmonary function after whole lung irradiation in pediatric patients with solid malignancies. Cancer 2012;118:1450-1456.

29 Huang TT, Hudson MM, Stokes DC, Krasin MJ, Spunt SL, Ness KK. Pulmonary outcomes in survivors of childhood cancer: a systematic review. Chest 2011;140:881-901.

30 Freudenberger TD, Madtes DK, Curtis JR, Cummings P, Storer BE, Hackman RC. Association between acute and chronic graft-versushost disease and bronchiolitis obliterans organizing pneumonia in recipients of hematopoietic stem cell transplants. Blood 2003;102: 3822-3828.

31 Schwarer AP, Hughes JM, Trotman-Dickenson B, Krausz T, Goldman JM. A chronic pulmonary syndrome associated with graft-versushost disease after allogeneic marrow transplantation. Transplantation 1992;54:1002-1008.

32 Patriarca F, Skert C, Sperotto A, Damiani D, Cerno M, Geromin A, Zaja F, Stocchi R, Prosdocimo S, Fili' C, et al. Incidence, outcome, and risk factors of late-onset noninfectious pulmonary complications after unrelated donor stem cell transplantation. Bone Marrow Transplant 2004;33:751-758.

33 Chakrabarti S, Collingham KE, Marshall T, Holder K, Gentle T, Hale G, Fegan CD, Milligan DW. Respiratory virus infections in adult T celldepleted transplant recipients: the role of cellular immunity. Transplantation 2001;72:1460-1463.

34 Srinivasan A, Wang C, Srivastava DK, Burnette K, Shenep JL, Leung W, Hayden RT. Timeline, epidemiology, and risk factors for bacterial, fungal, and viral infections in children and adolescents after allogeneic hematopoietic stem cell transplantation. Biol Blood Marrow Transplant 2013;19:94-101.

35 Hoffmeister PA, Madtes DK, Storer BE, Sanders JE. Pulmonary function in long-term survivors of pediatric hematopoietic cell transplantation. Pediatr Blood Cancer 2006;47:594-606.

36 Leung W, Ahn H, Rose SR, Phipps S, Smith T, Gan K, O'Connor M, Hale GA, Kasow KA, Barfield RC, et al. A prospective cohort study of late sequelae of pediatric allogeneic hematopoietic stem cell transplantation. Medicine (Baltimore) 2007;86:215-224.

37 Ghalie R, Szidon JP, Thompson L, Nawas YN, Dolce A, Kaizer H. Evaluation of pulmonary complications after bone marrow transplantation: the role of pretransplant pulmonary function tests. Bone Marrow Transplant 1992;10:359-365.

38 Goldberg SL, Klumpp TR, Magdalinski AJ, Mangan KF. Value of the pretransplant evaluation in predicting toxic day-100 mortality among blood stem-cell and bone marrow transplant recipients. J Clin Oncol 1998;16:3796-3802. 
39 Crawford SW, Fisher L. Predictive value of pulmonary function tests before marrow transplantation. Chest 1992;101:1257-1264.

40 Ramirez-Sarmiento A, Orozco-Levi M, Walter EC, Au MA, Chien JW. Influence of pretransplantation restrictive lung disease on allogeneic hematopoietic cell transplantation outcomes. Biol Blood Marrow Transplant 2010;16:199-206.

41 Piñana JL, Martino R, Barba P, Bellido-Casado J, Valcárcel D, Sureda $\mathrm{A}$, Briones J, Brunet S, Rodriguez-Arias JM, Casan $\mathrm{P}$, et al. Pulmonary function testing prior to reduced intensity conditioning allogeneic stem cell transplantation in an unselected patient cohort predicts posttransplantation pulmonary complications and outcome. Am J Hematol 2012;87:9-14.

42 Crawford SW, Longton G, Storb R. Acute graft-versus-host disease and the risks for idiopathic pneumonia after marrow transplantation for severe aplastic anemia. Bone Marrow Transplant 1993;12:225-231.

43 Baron F, Labopin M, Niederwieser D, Vigouroux S, Cornelissen JJ, Malm C, Vindelov LL, Blaise D, Janssen JJ, Petersen E, et al. Impact of graft-versus-host disease after reduced-intensity conditioning allogeneic stem cell transplantation for acute myeloid leukemia: a report from the Acute Leukemia Working Party of the European Group for Blood and Marrow Transplantation. Leukemia 2012;26: 2462-2468.

44 Weisdorf D, Zhang MJ, Arora M, Horowitz MM, Rizzo JD, Eapen M. Graft-versus-host disease induced graft-versus-leukemia effect: greater impact on relapse and disease-free survival after reduced intensity conditioning. Biol Blood Marrow Transplant 2012;18: 1727-1733.

45 Chien JW, Maris MB, Sandmaier BM, Maloney DG, Storb RF, Clark JG. Comparison of lung function after myeloablative and 2 Gy of total body irradiation-based regimens for hematopoietic stem cell transplantation. Biol Blood Marrow Transplant 2005;11: 288-296.

46 Singh AK, Karimpour SE, Savani BN, Guion P, Hope AJ, Mansueti JR, Ning $\mathrm{H}$, Altemus RM, Wu CO, Barrett AJ. Pretransplant pulmonary function tests predict risk of mortality following fractionated total body irradiation and allogeneic peripheral blood stem cell transplant. Int J Radiat Oncol Biol Phys 2006;66:520-527.

47 Quanjer PH, Weiner DJ, Pretto JJ, Brazzale DJ, Boros PW. Measurement of $\mathrm{FEF}_{25-75 \%}$ and $\mathrm{FEF}_{75 \%}$ does not contribute to clinical decision making. Eur Respir J 2014;43:1051-1058.

48 Reynaud-Gaubert M, Thomas P, Badier M, Cau P, Giudicelli R, Fuentes $P$. Early detection of airway involvement in obliterative bronchiolitis after lung transplantation. Functional and bronchoalveolar lavage cell findings. Am J Respir Crit Care Med 2000;161:1924-1929.

49 Sritippayawan S, Keens TG, Horn MV, Starnes VA, Woo MS. What are the best pulmonary function test parameters for early detection of post-lung transplant bronchiolitis obliterans syndrome in children? Pediatr Transplant 2003;7:200-203. 